Although the primates and the guinea pig are the only warm-blooded creatures (so far as is known) which cannot synthesize their own requirements of ascorbic acid, it is probable that in many other animals and birds the diet contributes to the ascorbic acid found in the body tissues.

Ascorbic acid is an indispensable hydrogen carrier in the metabolism of animals. It is known that the metabolism of mature birds of different species varies more nearly with the 0.66 power of body weight than the 0.73 power as appears to be the case with mammals?. It seems probable that the higher plasma ascorbic acid level of birds is related to the higher metabolism of avian tissues compared with those of mammals.

E. H. Hipsley, medical officer-in-charge of the Australian Institute of Anatomy, Canberra, gave advice and assistance with this study.

Kostas KaLnenas

c/o Royal Hobart Hospital,

Hobart, Tasmania.

Dec. 6.

${ }^{1}$ Farmer, C. J., and Abt, A. F., Proc. Soc. Exp. Biol. and Med., 34, $146(1936)$.

2 Pecover, V., Aust. J. Exp. Biol. and Med., 25, 175 (1947).

${ }^{3}$ Satterfeld, G. H., Bell, T. A., Cook, F. W., and Holmes, A. D., Poul. Sci., 24, 139 (1945).

${ }^{4}$ Munsell, H. E., Cuadros, A. M., and Suarez, R. M., J. Nutrition 28, 383 (1944)

${ }^{5}$ Rasmussen, R. A., Cole, C. L., Miller, M. J., and Thorpe, jun., F., Animal Science, 3, $340(1944)$.

6 Pecover, V., Norris, T. L., and Clements, F. W., Med. J. Austral., 481 (April 19, 1947). "Brody, S.; "Bioenergetics and Growth" (Reinhold Pub. Co., New
York, 1945).

\section{Symbiosis and Phylogenesis in the Isoptera}

SOME years ago-in 1924- I discovered bacteriocytes in the fat tissue of an Australian termite, Mastotermes darwiniensis, and I fully realized the phylogenetic significance of this discovery. My interpretation was confirmed by the researches of Kock, a pupil of Buchner.

I asserted, quite emphatically, that Mastotermes alone among termites demonstrate the bacterial symbiosis which every cockroach presents. I had not found bacteriocytes in Reticulitermes lucifugus (Rhinotermitidæ), Calotermes flavicollis (Kalotermitidæ), or Termopsis (Hodotermitidæ); but I had no opportunity of studying Archotermopsis, and I could only assume the absence of bacteriocytes from the fact that Imms, studying $A$. wroughtoni, observed nothing of the kind.
I am now able to state that, from a recent examination of specimens of $A$. wroughtoni, some of which have kindly been given me by Emerson (Chicago), that this archaic species of termite has neither bacteriocytes like Mastotermes nor any feature-for example, bacteria scattered through the fat tissuethat could represent rudiments of an ancient symbiosis.

Considering all the evidence, $I$ feel that the order Isoptera should be divided into two suborders: Mastotermitidæ and Termitidæ, the first with one family, one genus and one living species only.

The primitive characters of $M$. darwiniensis prove the archaicness of the suborder; such specialized characters as it has---like the complications of nestbuilding capacities and of social life - show the extent of its evolution since the Eocene (at least).

Perhaps further study of the hypermastigin symbionts would give other evidence to show whether Mastotermitidæ should be separated from all the other Isoptera or not.

$$
\text { C. JUCCI }
$$

Istituto di Zoologia "L. Spallanzani", Università, Pavia.

$$
\text { Dec. } 10 .
$$

\section{New Vectors of Strawberry Viruses}

FRAzIER ${ }^{1}$ has reported recently that certain strawberry viruses in California are transmissible by five species of aphids in addition to the long-established vector, and common strawberry aphid, Pentatrichopus (Capitophorus) fragoefolii (Ckll.) ${ }^{2}$. In Britain only $P$. fragcefoli $i$ and the closely related $P$. tetrarhodus Walk. were shown ${ }^{3}$ to transmit crinkle, and only the former is known to transmit yellow-edge $e^{4}$.

Experiments at East Malling showed, in 1950, that the aphids Myzus ascalonicus Doncaster and Acyrthosiphon malvoe subsp. rogersii (Theob.) could transmit two components of the strawberry virus complex, and this was confirmed in 1951. Aulacorthum solani (Kltb.) failed to transmit any of the viruses. The relevant details of some of the tests are given in the accompanying table.

The aphids were allowed long feeding periods of several days on plants infected with both mild crinkle (short persistence), crinkle and yellow-edge (long persistence) viruses. Long test-feeding periods on $F^{\prime}$. vesca plants were also used, so that the aphids would have conditions known to be suitable for a

\begin{tabular}{|c|c|c|c|c|c|c|}
\hline \multirow{2}{*}{ Aphid species* } & \multirow{2}{*}{ Virus source } & \multirow{2}{*}{$\begin{array}{l}\text { Infection feed } \\
\quad \text { (days) }\end{array}$} & \multirow{2}{*}{$\begin{array}{l}\text { Test feed } \\
\text { (days) }\end{array}$} & \multirow{2}{*}{$\begin{array}{l}\text { Aphids } \\
\text { per plant }\end{array}$} & \multicolumn{2}{|c|}{ Test plants } \\
\hline & & & & & Infected & Symptoms \\
\hline $\begin{array}{l}\text { Acyrthosiphon malva } \\
\text { subsp. rogersii } \\
\text { Aulacorthum solani }\end{array}$ & $\begin{array}{l}\text { yellow-edge } \\
\quad \text { and crinkle } \\
\text { criukle } \\
\text { mild } \\
\text { crinkle } \\
\text { vein-clearing } \\
\text { yellow-edge } \\
\quad \text { and crinkle } \\
\text { yellow-edge } \\
\text { and crinkle } \\
\text { vein-clearing } \\
\text { crinkle }\end{array}$ & $\begin{array}{r}4 \\
10 \\
9 \\
2 \\
2 \\
10 \\
5 \\
2 \\
3 \\
4 \\
3 \\
4 \\
2 \\
5 \\
5 \\
2\end{array}$ & $\begin{array}{r}7 \\
9 \\
10 \\
7 \\
3 \\
10 \\
1 \\
5 \\
7 \\
6 \\
4 \\
1 \\
1 \\
8 \\
8 \\
8\end{array}$ & $\begin{array}{r}5 \\
10 \\
10 \\
10 \\
10 \\
20 \\
10 \\
10 \\
10 \\
50 \\
10 \\
10 \\
5 \\
10 \\
10 \\
10\end{array}$ & $\begin{array}{l}1 / 5 \\
5 / 10 \\
2 / 5 \\
1 / 5 \\
2 / 2 \\
1 / 3 \\
1 / 3 \\
0 / 5 \\
0 / 8 \\
0 / 3 \\
1 / 5 \\
0 / 5 \\
1 / 10 \\
3 / 8 \\
0 / 5 \\
1 / 5\end{array}$ & $\begin{array}{l}\text { vein-clearing, } \\
\text { crinkle, vein-clearing } \\
\text { crinkle } \\
\text { crinkle } \\
\text { vein-clearing } \\
\text { mild crinkle } \\
\text { vein-clearing } \\
\text { vein-clearing } \\
\text { vein-clearing } \\
\text { vein-clearing } \\
\text { crinkle }\end{array}$ \\
\hline
\end{tabular}
high rate of virus transmission by $P$. fragoefoli ${ }^{5}$. The

* Provided and determined by Dr. G. H. I. Dicker. 